Rights and the interesting experience of the Inter-American Commission on Human Rights would seem to justify the promotion of similar commissions in other regions, the Study Group merely explored the various issues involved in such proposals and did not present any firm recommendations. The trend of the discussions was, nevertheless, favorable to the creation of additional regional commissions "on the direct and exclusive initiative of the States comprising a given region," with United Nations assistance if requested. In any case, the relationship between the existing and new regional commission on human rights and the new United Nations organization (UNOPHR) is likely to present some difficulties, and may require special agreements between UNOPHR and each regional commission.

7. Relationship to Other International Organizations. In addition to the regional organizations, there are several other international organizations, including such specialized agencies as the International Labor Organization and the United Nations Educational, Scientific and Cultural Organizations, which have been active in human rights for many years and which are responsible for the implementation of important international conventions on human rights. While all the United Nations activities should be concentrated in the new organization, this organization should in no way impinge on the work of the other international organizations active in the human rights field. More efficient concentration of the United Nations activities should make it easier to co-ordinate the work of the United Nations with that of these other organizations and thus provide a more effective protection for human rights throughout the world.

LOUIS B. SOHN

\title{
SHOULD THE UNITED STATES RATIFY THE COVENANTS? A QUESTION OF MERITS, NOT OF CONSTITUTIONAL LAW
}

The adoption by the General Assembly in December, 1966, of the Covenant on Economic, Social and Cultural Rights as well as the Covenant on Civil and Political Rights with its attached Optional Protocol providing for individual petitions, presents once more the issues of whether the United States Government should seek to ratify these instruments and what obstacles would stand in the way of obtaining Senate consent to their ratification. The writer once considered these questions ${ }^{1}$ shortly before the completion of the Human Rights Commission's final drafts in 1954. Although there are a few significant differences between the $\mathrm{Hu}$ man Rights Commission's provisions and those adopted by the General Assembly after protracted consideration by the Third Committee, the issues and arguments remain largely the same.

On the policy level, the basic problem still is whether the United States should ratify these instruments, despite their many imperfections, in view of our past history and our present rôle in the world. On the legal level, the same debate continues as to whether there are any valid constitutional

1 MacChesney, "International Protection of Human Rights in the United Nations," 47 Northwestern U. Law Rev. 198(1952). 
objections to the adoption by the United States of human rights conventions. It may well be urged that the so-called legal objections are in fact bottomed on policy considerations. However, in this comment they will be separated for purposes of discussion.

There were a number of provisions in the Human Rights Commission's final drafts that presented difficult questions for the United States. The first article in both Covenants, dictated by the General Assembly itself, provided for the "right" of self-determination, defined as including permanent sovereignty over natural resources. Moreover, after the announcement by Secretary Dulles in 1953 that the United States would not sign the Covenants and would no longer participate as actively in their formulation, the Covenants were made applicable to federal states without exception or limitation and the earlier United States advocacy of a federal-state clause was dropped. Furthermore, no provision was made for reservations. Finally, the refusal of the Commission to adopt any provision in the Economic and Social Covenant for the protection of property rights along the lines of Article 17 of the Universal Declaration of Human Rights was a glaring defect from the United States standpoint. Apart from these more general matters, the article in the Civil and Political Covenant prohibiting advocacy of national, racial, or religious hatred that would incite discrimination, hostility or violence ereated the further problem of reconciliation with our constitutional guarantee of freedom of speech.

During the twelve years that the draft Covenants were being considered and revised by the Third Committee, new provisions were adopted which, to say the least, made it no easier for the United States and certainly increased the probabilities of substantial opposition to ratification. The mandatory Article 1 in both Covenants on the "right" of self-determination and permanent sovereignty over natural resources was reaffirmed in stronger language, although a reference to obligations arising out of international law was added. Moreover, an additional separate article was inserted in each Covenant reasserting this same alleged inherent "right" to "fully and freely" dispose of their natural resources. To the previous provision in the Civil and Political Covenant prohibiting advocacy of hatred that would incite violence was added a paragraph providing for prohibition of war propaganda. Even more disturbing was the addition to Article 2 of the Economic and Social Covenant, which, in the second paragraph, broadly prohibited discrimination, of a new paragraph three authorizing "developing countries" to determine to what extent they would discriminate against non-nationals with respect to the economic rights recognized in the Covenant. While making these changes, none of the questionable provisions or omissions that have been mentioned in the draft Covenants were deleted or rectified in the Covenants adopted by the General Assembly.

Another important aspect of the Covenants is, of course, the efficacy of their implementation (enforcement) provisions. A rational decision with respect to their ratification must include a judgment as to whether 
they contain meaningful advances in enforcement or are merely a reiteration and extension of the standards of achievement previously stated in the original Declaration. From this standpoint it is somewhat ironic to note that the voting majorities that extended the scope of the substantive provisions at the same time weakened considerably the provisions for enforcement, particularly with respect to the final implementation provisions in the Civil and Political Covenant.

The Human Rights Commission draft authorized a Human Rights Committee created under the Covenant to receive complaints by one state party against another state party, and if no solution was reached, to report to the parties concerned and for later publication their opinion as to whether the Covenant had been breached, with subsequent right of either party to bring the case before the International Court of Justice. In the General Assembly version, the Human Rights Committee may receive state complaints against another state only if both states have declared their willingness to be complained against. In such case the Committee, if no solution has been reached, can now only report the facts briefly to the parties concerned with no further recourse except to an ad hoc Conciliation Com. mission appointed by the Committee with the free consent of the contestants. If this further procedure reaches no acceptable solution, the Commission shall report the facts as well as its "views" on the possibilities of amicable solution to the parties concerned. With respect to states parties to the Covenant that have not declared their willingness to receive complaints, the Committee's only "measure of implementation" is to receive reports from the states parties, study them, and then transmit "general" comments to the parties and to the Economic and Social Council. All of the steps under all these procedures require extended time in order to be compatible with the sensitivities of sovereign states. It would be difficult to imagine weaker measures of implementation. It is doubly ironic that these measures should effectively prevent the meaningful enforcement so feared by opponents of international protection of human rights and yet serve as a symbol of "creeping internationalism."

On the other hand, the addition of an Optional Protocol for individual petitions annexed to the Civil and Political Covenant is a modest but significant advance over the Human Rights Commission drafts which made no provision for individual complaints integrally or separately. States parties to the Optional Protocol must at least respond to the charges, even though the Human Rights Committee's powers are limited to a forwarding of the Committee's "views" to the contestants, and the right to include a summary of its activities under the Protocol in its annual report to the General Assembly. So far as implementation measures in the Economic and Social Covenant are concerned, there has been no substantial change in the reporting measures there provided. It may be said to have been slightly strengthened by permitting the Economic and Social Council to make recommendations of a "general" nature.

The purpose of the foregoing discussion was not to examine in detail the various provisions of the Covenants but to underline the problems 
which make difficult the decision for the United States Government with respect to the desirability of signing and then pressing for ratification of these major Human Rights Conventions. The arguments for and against ratification by the United States of treaties providing for international protection of human rights have been frequently stated and will not be repeated here. The view of this comment is that these important and complex issues should be decided on their merits without the distracting confusion introduced by the constitutional objections that have constantly been advanced for many years by the Standing Committee on Peace and Law Through the United Nations of the American Bar Association, and ultimately in almost all cases endorsed by the House of Delegates of that Association.

Recent experience with the efforts to obtain ratification of the three human rights treaties sent to the Senate by President Kennedy in 1963 makes it reasonably certain that the Standing Committee will similarly oppose the ratification of the Covenants on the same constitutional grounds. The three treaties were the Supplementary Convention on the Abolition of Slavery, the Convention on the Abolition of Forced Labor, and the Convention on the Political Rights of Women. Sending these three treaties to the Senate was in pursuance of a new policy announced by the Kennedy Administration, which stated that it would consider each human rights treaty on its own merits. In forwarding to the Senate these three treaties the Department of State asserted that their ratification would require no change in existing United States law, and thus would not affect the existing federal-state structure, a statement which the Standing Committee does not appear to challenge.

In the Report ${ }^{2}$ of that Committee supporting their recommendation against ratification of any of the three treaties, there was constant invocation of what might be called the "wedge" argument: that ratification of these three treaties would open the door to future ratification of what were presumably considered more far-reaching and even less desirable treaties such as the Covenants. The Report clearly threatened that ratification by the United States of these treaties would lead to a revival of proposals for constitutional limitation of the agreement-making power. In discussing the absence of a federal-state clause, for example, the Report charged that any change by treaty of the existing federal-state structure would "alter our form of government," despite the power to make treaties in the Constitution itself. Once more, as in the Bricker controversy, it is implied that the decision in Missouri v. Holland was itself unconstitutional!

It is generally understood that the 1953 change of policy by Secretary Dulles was in response to the threat of the Bricker Amendment. It is not unfair to suggest that the major force behind the Bricker Amendment was the Standing Committee, and the American Bar Association in sup-

22 Int. Lawyer 600 (1967). Although labeled as an excerpt, the Editor-in-Chief of the International Lawyer stated that "the main thrust of the report remains umim. paired." Ibid. at 601 . 
port of the position of the Standing Committee. It is most interesting to note in the Report the use of this change of position as an argument against adoption of the three treaties. Thus, Dulles' own statement and those of other officials following policy thus established are cited to show that the three treaties are not appropriate subjects of the treaty power. In view of the proximate cause of the change of position, this is indeed a "bootstrap" argument.

The basic constitutional position of the Report is a continuation of views originally espoused in the Bricker controversy. The Standing Committee's thesis would seem to be that the constitutional test is whether a matter is of a domestic nature or is of international concern, and that the relation between a State and its own citizens is the essence of a domestic question and cannot become a matter of international concern. The writer agrees with Professor Gardner ${ }^{3}$ and with the statement ${ }^{4}$ of eight members of the Council of the Section of International and Comparative Law of the American Bar Association that there is no substance to this constitutional argument and that it has no support in either Supreme Court decisions or prior practice. There is a vital difference between the established test of "all proper subjects of negotiation" and whether a particular sub. ject matter is, apart from its international impact, otherwise within domestic jurisdiction. If the subject of the treaty is properly a matter for international negotiation, it is a constitutional treaty, even though the subject is also domestic. ${ }^{5}$ The Standing Committee also appears to rely on Article 2, Paragraph 7, of the United Nations Charter as re-enforcing its position. Certainly Article 2, Paragraph 7, of the Charter has never been part of our constitutional law and the Committee appears to admit that at least internationally a treaty can remove a matter from the previously applicable domestic jurisdiction clause. ${ }^{6}$

It should be noted that the Standing Committee's recommendations were not endorsed in toto by the Council of the Section nor ultimately by the House of Delegates. At an earlier stage the Section Council favored ratification not only of the Supplementary Slavery Convention but also of the Forced Labor Convention with an "understanding," but did not favor ratification of the Political Rights of Women Convention. Ultimately, at the 1967 Annual Meeting of the American Bar Association in Honolulu, the Section's Council and the Section favored only the ratification of the Supplementary Slavery Convention, opposed the ratification of the Political Rights of Women Convention, and took the position that no action should be taken on the Forced Labor Convention. After spirited debate in the House of Delegates, the position of the Standing Committee was rejected and the position of the Section was approved, a motion to

3 Gardner, "A Costly Anachronism," 53 A.B.A.J. 907 (1967).

*2 Int. Lawyer 638(1967). Joint statement of Benjamin Busch, Walter E. Craig, Donald K. Duvall, Harry A. Inman, Robert Layton, Leonard C. Meeker, Charles R. Norberg and John R. Stevenson. s Ibid.

6 In the context of the Bricker Amendment, the writer has stated his views on the constitutional questions involved. See MacChesney, "The Fallacies in the Case for the Bricker Amendment," 29 Notre Dame Lawyer 551(1954). 
endorse all three treaties having been previously rejected. ${ }^{7}$ Subsequently, the Senate Committee on Foreign Relations and the Senate itself acted in accord with the Section and Association positions. Thus the United States has now ratified its first human rights treaty prepared under the auspices of the United Nations, and this is one tiny step forward. However, the rejection of the two other treaties does not augur well for the prospects of successful ratification of the Human Rights Covenants.

The complex and important issues involved in the decision as to whether the United States should ratify the Covenants and the Protocol in their present form should not be obscured by the interjection of constitutional objections that are lacking in substance. In view of the recent experience with the three treaties previously discussed, it may be sanguine to urge that the Covenants should be considered on their merits. Some of the difficulties for the United States have been mentioned. They should be balanced against the positive advantages for this country in participating in the great quest for international protection of human rights. Whatever the ultimate judgment, the United States should make this crucial decision in the light of all the competing policy considerations. It would not be worthy of our heritage and our responsibilities to abstain on spurious constitutional grounds.

Brunson MacChesney

T The debate is reported in 53 A.B.A.J. 963 at $972-976(1967)$. 